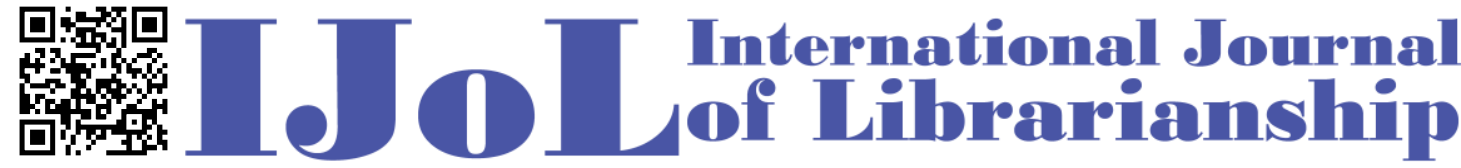

ISSN: 2474-3542 Journal homepage: http://journal.calaijol.org

\section{Organic Learning in Undergraduate Library Instruction}

\author{
Kanu A. Nagra and Bernadette M. López-Fitzsimmons
}

\begin{abstract}
:
Organic learning engages undergraduates in discovering new knowledge based on prior learning through variety of guided activities that stimulate inquiry-based learning and critical thinking in the research process. Some activities include searching, browsing, accessing, gathering, evaluating, assessing, reflecting, organizing, linking, and synthesizing. Learning how to access information by using a variety of search strategies as well as delivery platforms such as Google, discovery, individual databases, and the internet can be overwhelming and challenging. When students discover how to search and access desired sources through a variety of explicitly designed information literacy instructions with clearly defined learning outcomes, they take ownership of developing their learning and research skills. Through organic learning, they experience lightbulb moments, asking questions, discussing topics, and then searching again for more information. Organic learning unconsciously involves students in self-education, engaging them in the research process without pressuring them to practice redundant, rote exercises. Often undergraduates encounter difficulty in conceptualizing the research process as complex and multi-faceted. The authors argue that organic learning strategies to activate prior learning that builds advanced searching skills and increase new scholarly knowledge.
\end{abstract}

To cite this article:

Nagra, K.A., \& López-Fitzsimmons, B.M. (2019). Organic Learning in Undergraduate Library Instruction. International Journal of Librarianship, 4(1), 72-92.

To submit your article to this journal:

Go to http://ojs.calaijol.org/index.php/ijol/about/submissions 


\title{
Organic Learning in Undergraduate Library Instruction
}

\author{
Kanu A. Nagra, Borough of Manhattan Community College, City University of New York \\ (CUNY), New York, N.Y. \\ Bernadette M. López-Fitzsimmons, Manhattan College, Riverdale, N.Y.
}

\begin{abstract}
Organic learning engages undergraduates in discovering new knowledge based on prior learning through variety of guided activities that stimulate inquiry-based learning and critical thinking in the research process. Some activities include searching, browsing, accessing, gathering, evaluating, assessing, reflecting, organizing, linking, and synthesizing. Learning how to access information by using a variety of search strategies as well as delivery platforms such as Google, discovery, individual databases, and the internet can be overwhelming and challenging. When students discover how to search and access desired sources through a variety of explicitly designed information literacy instructions with clearly defined learning outcomes, they take ownership of developing their learning and research skills. Through organic learning, they experience lightbulb moments, asking questions, discussing topics, and then searching again for more information. Organic learning unconsciously involves students in self-education, engaging them in the research process without pressuring them to practice redundant, rote exercises. Often undergraduates encounter difficulty in conceptualizing the research process as complex and multi-faceted. The authors argue that organic learning strategies to activate prior learning that builds advanced searching skills and increase new scholarly knowledge.
\end{abstract}

Keywords: Organic learning, undergraduates, library instruction, student-driven learning, student-centric learning, active learning, constructivist learning, autonomous learning, selfdirected learning, student-centered learning, individualized learning, student-regulated learning, discovery teaching and learning, holistic learning

\section{INTRODUCTION}

\section{Overview}

Organic learning is a healthy way of learning to absorb essential learning nutrients and to satisfy the growing appetite for more knowledge for success in academic, professional and personal endeavors. This paper discusses specific teaching approaches, pedagogical styles, and classroom management strategies that support meaningful and purposeful learning in twenty-first-century undergraduate library instruction to accomplish organic learning. The authors argue that organic learning in library instruction focuses on student-centric learning where undergraduates participate in the research process at different stages of cognitive development. Students discover 
how to use information from a wide gamut of sources and manipulate multiple search strategies across several types of information technology platforms.

The authors use several terms interchangeably and synonymously to represent organic and student-centric learning, including student-regulated, student-directed, student-centered, and student-managed learning. They also employ terms that emphasize self-education, including selfregulated, self-directed, and self-managed learning. All of these terms refer to learning environments where students explore and discover new knowledge based on prior knowledge, engaging in inquiry-based thinking processes -- reflecting, evaluating, analyzing, and synthesizing information. Though team work and collaboration are integral in organic learning, the endgame focuses on producing individual and independent lifelong learners who can easily adapt their skills and generate knowledge in a rapidly-changing, technologically-driven global world. The authors contend that organic or self-managed learning is based on constructivist principles; they explain how constructivism has accommodated millennials' learning needs. In this paper, the following words are used interchangeably and synonymously as well: undergraduates, students, learners, and millennials.

The authors recount their own experiences in which organic learning has been successful in classroom teaching and research assistance sessions, supporting the academic needs of diverse student populations at an urban community college and a four-year college in New York City. Concentrating on helping students understand the complex and iterative nature of the research process, they guide them in using a variety of sources, accessing information via multiple delivery platforms, evaluating the information found in the sources, thinking critically about the information and, finally, synthesizing the information into their research papers so that they include their own observations and conclusions.

The article begins with an overview and definition of organic learning in twenty-first century undergraduate library instruction classrooms, reference desk experiences, and research consultations. This is followed by a conceptual analysis based on ACRL IL framework, methods, review of the literature, and a discussion of specific teaching approaches, classroom management strategies, instructional designs, and pedagogies used in library instruction.

Student-centric and student-managed learning supports students' involvement in the research process under the librarians' guidance while fulfilling courses' research requirements. As students move through the research process - examining different types of information in multiple kinds of sources presented in various formats -- they become aware of how to discern authoritative information from inaccurate, biased or fake news. This process facilitates the development of critical thinking skills, engaging students in learning disciplinary academic content that renders them accountable for participating in successful learning as they generate new knowledge. Through discovery, students realize that "information creation as a process" (ACRL framework no. 2, 2019, para. 7), emphasizing that "information has value" (ACRL framework no. 3, 2018, para. 7).

As their skills and knowledge evolve, undergraduates become responsible for directing and managing their own successful learning. Acknowledging that they themselves are involved in scholarly investigations makes students more accountable for their own learning and the development of proficient research skills. This type of learning engages students in activities in which they learn as they explore, discover, find, evaluate, assess, synthesize, and, ultimately, create new knowledge. Not only do undergraduates develop self-efficacy and self-confidence 
with regard to their abilities to conduct research successfully, they also recognize that they are contributing new knowledge to academic and scholarly endeavors. When librarians and teaching faculty "believe strongly in their instructional efficacy support development of students' intrinsic interests and academic self-directedness" (Bandura, 1997/1999, p. 20). As they witness their contributions to "scholarship as conversation" (ACRL framework no.5, 2019, para. 7), learners participate in the experience of "learning to learn," delving into "research as inquiry" (ACRL framework no. 4, 2019, para. 7) as they develop inquiry-based thinking skills (Thoutenhootd \& Pirrie, 2015; Wingate, 2007).

The authors of this paper use the ACRL IL framework in organic learning as studentcentered and student-regulated learning in library instruction classroom, reference desk sessions, and research consultations based on the ACRL framework. Wingate emphasizes the concept of "learning to learn" at the undergraduate level where students learn from contexts supported by their learning environments (2007, p. 392). The authors use this concept in conjunction with the ACRL framework, explaining research that supports student-driven learning experiences in successfully developing fluid library and information literacy skills. These skills are necessary in the academic, professional, and personal pursuits in twenty-first century life.

\section{ORGANIC LEARNING}

\section{Conceptual Analysis: The ACRL Framework for Information Literacy}

In recent decades, there has been an emphasis on experiential learning at all educational levels, including community college, four-year colleges, university, and professional and graduate programs. Experiential learning incorporates theory in practical applications such as hands-on activities that engage students in exploring and discovering new knowledge as well as developing additional technological skills. According to Dewey's (1910) metatheory, undergraduates' who participate in active rather than passive learning are able to apply inferential thinking to the process of action and then engage in reflecting. Reflection on newly acquired knowledge stimulates critical thinking and increases learning.

Engaging in activities affords students the opportunities to be involved in their own learning and, thereby, become accountable for their own learning. As they recognize their own abilities to learn, they are motivated to take more risks in learning, building new knowledge, and developing a variety of skills built on previously learned knowledge and skills. In social psychology theories or substantive theory -- including Gestalt theory, group dynamics, field theory, and change theory - scholars claims that action research includes "authentic learning, or performance-based assessment practice," in library instruction (Lewin \& Lewin,1948, 22). These practices, known as formative assessments, include the use of rubrics, journals, portfolios, and specific interventions that address stages of the information search process (Lewin \& Lewin, 1948; Kuhlthau, 1986) such as brainstorming, mind maps, graphic organizers, statements of intent, anticipatory slips, exit slips, KWL (already know; want to know; ultimately will know/learn) charts, gaming, and peer review (Kuhlthau, 1986). Based on observing the use of these interventions, the evidence indicates that undergraduates' can "self-diagnose and selfremediate" as they document progress in their research and develop inquiry-based skills based on logical, sequential, and analytical thinking. These successful learning experiences support a "can do" attitude toward learning to research and use information literacy skills. With practice in 
groups and individually, millennials can increase their self-efficacy and self-confidence (Clark, 2017, p. 416).

In higher education, experiential learning is often equated to learning autonomously rather than scientific, formulaic learning. While the late nineteenth and twentieth centuries focused on traditional teacher-centric education using memorization and rote exercises to prepare learners for the industrial revolution's jobs that consisted of redundant tasks, the late twentieth and twenty-first century education prepares students to problem-solve, adapt skills, and generate new knowledge to meet the information age's challenges in a fiercely competitive, rapidly changing, and technologically driven global ecosystem (Elder, 1997/1999). Educational methods and pedagogies used in the nineteenth and early twentieth centuries prepared students for dronelike jobs that no longer exist. These teaching techniques have gradually been replaced by more compelling instructional practices that promote concentration, attention to detail, assessing and evaluating data, and analytical thinking - all necessary in the twenty-first century and beyond.

Organic learning takes place "through the culture in which one lives — where learning is derived from, or characteristic of culture and society" (Morrison, 2014, para. 1). Students learn from experience and their engagement at different capacities throughout a self-directed learning process. For the most part, organic learning adheres to the following stages of experiential learning:

1. Observing a model

2. Participating in a hands-on or small group activity

3. Exploring the outcomes by reflecting, examining, evaluating, assessing, and synthesizing

4. Sharing their findings with peers

5. Synthesizing the new knowledge, making connections to other learned lessons

6. Assuming responsibility for successful learning. (Morrison, 2014; Teaching Excellence in Adult Literacy Staff at the American Institutes for Research, 2010)

In the last several decades, academic and research libraries have been collaborating with colleagues in higher education to adapt "learning outcomes, tools, and resources" at their respective institutions to include "information literacy concepts and skills into their curricula" (ACRL Frameworks, 2019, para. 9). Organic learning practices in library instruction embrace to the six concepts of information literacy framework of ACRL 2019 listed below:

1. Authority is constructed and contextual

2. Information creation as a process

3. Information has value

4. Research as inquiry

5. Scholarship as conversation

6. Searching as strategic exploration (ACRL Framework, 2019, para.7)

Each standard concept of the ACRL information literacy framework supports engaging students at the different levels of research as well as in variety of organic learning activities.

In the following sections, the authors discuss how active learning practices -- including teaching approaches, classroom management strategies, and purposeful instructional designs -facilitate students' organic learning at several stages as well as the six standard concepts of the ACRL information literacy framework. They speak to specific instructional styles, lecture/lesson designs, and classroom management techniques that support meaningful and purposeful learning. 


\section{METHODS}

The review of the literature in this paper supports organic learning in library instruction in academic libraries. Based on their own experience, the authors of this paper explain organic learning instructional strategies for one-shot information literacy (IL) classes, credit-bearing IL courses, research consultations, and reference sessions. They describe how these pedagogies, techniques, and practices prepare students for academic success and lifelong learning.

\section{LITERATURE REVIEW}

Plato juxtaposed two arguments about education: instruction can dictate content to learners so that they commit to memory facts and/or ideas; learning environments can support students discovering knowledge on their own (Thomas, 2013). These opposing viewpoints introduced ongoing discussions on learning environments that have endured for centuries. While Aristotle and the Romans included coercion and corporal punishment in education, Plato took a different stance, introducing the concept of "play" in learning (Thomas, 2013, p. 5). Rather than following a master teacher in a rigid, restrictive environment (Thomas, 2013) often managed with punitive measures, Plato's play facilitates successful learning by sparking interests, stimulating epiphanies, and developing deeper intellectual comprehension.

In contemporary learning environments, Plato's play could be interpreted as gaming, where learning takes place autonomously in a comfortable, supportive learning environment. Elzen and Roush (2013) posit that gaming unites undergraduate learners in expressing their shared interests in the library, exposing them to potentially useful resources for academic, professional, and personal endeavors (p. 809). Since they often lack logic-based thinking skills for conducting investigative inquiries, millennials can learn what they need to learn about research as well as gain a deeper intellectual understanding in academic disciplines through gaming in libraries (D’Angour, 2013; Hunnicutt, 1990). Thus, learning students would benefit from gaming by developing critical thinking skills and becoming cognizant of different types of resources which is in sync with the ACRL information literacy framework no. 4, "research as inquiry," and no. 6, "searching as strategic exploration" (ACRL, 2019, para. 7).

Organic learning can be viewed as "student-centered learning"; both terms present students as "owners of their learning" (Lee \& Hannafin, 2016, pp. 707-708), rendering them accountable for their involvement in learning processes, including searching for, accessing, evaluating and using information from a variety of authoritative sources.

Though organic learning is widely used at all educational levels, academics and scholars have not yet documented a significant amount of evidence that provide guidelines to educators. Currently, there is a paucity of empirical data to support organic learning's impact on student engagement and autonomous learning. Frequently, learners remember the experience but cannot recall the content and re-use skills. It is important, therefore, for organic learning to be purposeful and strategic, following intentional instructional designs to guard against education becoming merely entertainment, recreation, and amusement.

The shift in education has increasingly been emphasizing a constructivist approach to examine effective and ineffective teaching and learning in higher education. Constructivist 
psychologists view the process of learning academic disciplines and/or professional skills as a "quasi-autonomous process that is self-regulated" (Scheerens, 2015, p. 4). Constructivist learning takes places in a learning environment where there are no lectures, no demonstrations, and no presentations (Cooperstein \& Kocevar-Weidinger, 2004, p. 141). Instead, learners are presented with a prompt, usually a problem, case, or question. Working in small groups or pairs, students attempt to resolve the issue at-hand through exploration and discovery, analyzing and evaluating information from multiple sources. Below are the main highlights of constructivism:

1. Learning is meaningful, purposeful, and authentic. Students interpret, analyze, and synthesize the accessed information. They must manipulate, discover, and create new knowledge based on prior knowledge, adding their contributions to the scholarly community.

2. New learning is built on prior knowledge. Students must make connections between old knowledge and new information. They must compare, question, challenge, investigate, accept or discard old information and beliefs to advance intellectually.

3. Learning is enhanced by social interaction in a democratic environment. Students have the opportunity to compare and share their ideas with peers, specialists, researchers, and others.

4. Learning occurs as conflicts are resolved. Whole class share provide learners with the opportunity to share their ideas with others as well as learn from other collaborators.

5. Meaningful learning is realized through authentic activities. Selected activities are based on learning in real life or researching for an assignment. (Cooperstein \& KocevarWeidinger, 2004; Scheerens, 2015)

From the premise of self-directed (student-directed) or self-regulated (student-regulated) learning based on constructivism has evolved the concept of organic learning. According to Ashton-Warner's (1963/1986) pedagogical philosophy, the "organic teaching methodology" (p. 2) is contextual, "arising from the immediate conditions of the context" allowing learning to occur based on the situation at-hand (Thompson, 2000, p. 91).

Active learning refers to real world activities founded on students' experience in life. In library instruction curricula, lectures and lessons are designed to facilitate reflection, creating opportunities for learners to interact with the accessed information at their respective cognitive and research levels (Finch \& Jefferson, 2013, p. 181). Successful organic learning focuses on two main areas: the teaching librarian/professor and the learning student. Concentrating on these areas diminishes teaching faculty's autonomy and creativity while placing more accountability on students' initiating, coordinating, managing and directing their own learning and academic achievements.

Student-centric learning is a holistic approach in which interactive experiences engage learners, providing extrinsic motivation that activates learners' self-awareness of their own abilities to learn successfully. The American Psychological Association (2019) states that selfefficacy "reflects confidence in the ability to exert control over one's own motivation, behavior, and social environment" (para. 1). In learning theory, self-efficacy supports students' intrinsic motivation to add new knowledge to prior knowledge by engaging in more autonomous learning experiences. Thus, students are able to expand their current knowledge by adding to it as more learning occurs. According to Bandura (1997/1999), "efficacy beliefs play a vital role in the development of self-directed lifelong learners (p. 17). Library instruction introduces a wide 
variety of information sources and research skills so that undergraduates cultivate lifelong learning skills.

Eventually, millennials can evolve as more intrinsically motivated individuals to learn in formal and informal learning environments, increasing self-efficacy and self-esteem. Extracurricular and co-curricular experiences foster formal (teacher-centric) and informal learning (student-centric) as well as the integration and synthesis of the two areas across academic disciplines and professional trainings.

At all levels of higher education, reconfiguring assessment strategies to encompass all aspects of institutional effectiveness and ineffectiveness primarily based on learning outcomes has become the norm. Most institutions focus on a central mission in sync with systematically and strategically coordinated curricula targeted at specific learning outcomes, many of which include organic learning experiences. State-of-the-art communication technologies in education are constantly monitoring and tracking effective and ineffective teaching styles and learning outcomes as well as instructional designs of curricula. Accreditors such as the Middle States Association (MSA), New York State Department of Education (NYSED), and others require rigorous self-study evaluations with empirical data, documenting numerous structural reforms in extensive reports submitted to local, state, federal, and regional educational agencies. These reports verify the effectiveness and ineffectiveness of centralization vs. decentralization, accountability, and evaluations based on syllabi with organic learning components, and curriculum mapping based on rubrics. Frequently, reports reflect mixed views and equivocal patterns, resulting in functional decentralization in some areas but centralization in other areas (Scheerens, 2015).

Organic learning is not merely entertainment in the classroom; rather, it is meaningful and purposeful learning intended to elicit higher order and inquiry-based thinking skills in information literacy classes. Self-regulated learning is another term that can be used for organic learning, and both terms focus on individualized or independent learning, placing the responsibility for successful learning on individual learners. Though the terms are often used interchangeably, "learning to learn" is defined as the "ability to pursue and persist in learning, to organize one's own learning, including the effective management of time and information, both individually and in groups" (Thoutenhoofd \& Pirrie, 2015, p. 73). Self-regulated or organic learning depends on "cognitive and affective processes that operate on the capacity of an individual to process information" for optimal academic success (Thoutenhofd \& Pirrie, 2015, p. 74).

Individualized, self-directed (student-directed) learning is focused on reaching specific learning outcomes, and this emphasizes self-generated and self-regulated learning based on personal initiative, perseverance, and the resilience of adapting learning skills in different learning environments - academic, professional, or personal. Another aspect of organic learning considers "compliance with pre-determined external norms" (Thoutenhoofd \& Pirrie, 2015, p. 74) with the assistance of facilitators such as a librarian and/or course teaching professor. It demands that learners be involved in and, responsible for, their own learning. Learning to learn is a theoretical concept introduced at the undergraduate level, but it and extends far beyond, differentiating learning in post-secondary education from that of grades K-12.

Traditional library instruction includes a tour of the online resources and services as well as a lecture about academic research protocols and style manuals. This is usually followed by 
having learners engage in hands-on activities using databases and their tools, increasing selfefficacy and self-esteem in conducting research. Self-efficacy plateaus, however, with this style of teaching (Clark, 2017); a continuum of increasingly challenging types of research assignments need to be added to the curricula so that learners continue evolving as savvy users of multiple types of information sources rather than losing or forgetting their skills. Bandura (1997/1999) posits that "self-regulatory skills will not contribute much if students cannot get themselves to apply the persistently in the face of difficulties stressors or competing attractions" (p. 18). Since they do not automatically transfer skills and re-apply knowledge, undergraduates need to develop "skills in regulating motivational, affective, and social determinants of their intellectual functioning as well as the cognitive aspects" (Bandura, 1997/1999, p. 18). Zimmerman (1990) maintains that learners who self-regulate well perform better academically than those who selfregulate poorly or not at all.

In the twenty-first century, teaching diverse populations at the community college and four-year colleges requires differentiation rather leveled lessons. Because students' unpreparedness for rigorous undergraduate academics (Ozga \& Sukhnandan, 1998; Drew, 2001) is common, academic learning support services- including the library- can facilitate their developing skills and expending knowledge in order to succeed in higher education and beyond (Ozga \& Sukhnandan,1998; Drew, 2001).

Organic learning borrows theoretical and practical applications from three areas: constructivist psychologists (Piaget, 1932, 1936, 1945, 1957, 1958/2013; Piaget \& Cook, 1952), social psychologists (Bruner, 1957, 1960, 1961, 1966, 1973; Vygotsky, 1962, 1978, 1987/1934), and behavioral psychologists (Skinner, 1938, 1948, 1951, 1953). Piaget's constructivism refers to individuals construct their own mental image of the world (Thomas, 2013). While Bruner claims that scaffolding should be used to provide learners with support until they are able to work independently without them. Vygotsky (1978) recommends that instructors focus on the level above students' current knowledge so that they can learn with assistance. Teaching a level above millennials' current knowledge is known as the "zone of proximal development" or “ZPD” (Vygotsky, 1978, p. 33).

In the twenty-first century learning classroom, differentiating lessons allows more advanced students to work on more challenging assignments while those who need support can use scaffolds until they catch up with their peers. Behaviorists like Skinner (1938, 1948, 1951, 1953). believe that instructors should dissect complex ideas into "chunks" or "learnable portions," spoon-feeding them to students in a logical, systematic sequence (Thomas, 2013, p. 77). Organic learning blends the theoretical concepts from these three areas to facilitate learning to learn. At the college level, there should be a systematic, logical, and comprehensive support structure so that successful learning takes place. Learning to learn is often a "complex development process involving changing perceptions, learning habits, and epistemological beliefs" (Wingate, 2007, p. 395).

In library instruction, there needs to be a consistent, gradual escalation of student learning taking place through embedding information literacy lessons in academic disciplinary teaching. As mentioned earlier, it is important to apply a holistic approach to learning, involving different contexts, strategic teaching methodologies, and a plethora of classroom management techniques. Learning in different contexts within a consistent structure is in sync with ACRL framework no. 1 - "authority is constructed and contextual" (ACRL, 2019, para. 7; Wingate, 2007, p. 397). 
To avoid focusing on students' deficiencies, community colleges and four year colleges have been approaching teaching and learning from a holistic approach. A basic element of this approach is to understand academic literacy as discipline-specific, and students must appreciate their role in this type of learning. Students cannot merely receive knowledge passively; rather, they must engage in critical and inquiry-based thinking, eventually creating new knowledge. This type of engagement is known as "learning to learn" and it can be explained in two ways:

1. Understand and recognize learning so that students evolve as independent learners.

2. Understand and recognize knowledge to become competent building new knowledge based on prior knowledge in academic disciplines. (Wingate, 2007, p. 394)

In sum, organic learning utilizes community building activities, having students collaborate in small groups where each individual assumes a designated charge such as notetaker, taskmaster, coordinator, or spokesperson. In these cooperative groups, students experience learning to learn, conducting research, sharing ideas, and creating new knowledge as interactive, dynamic, playful, and progressive. Social interaction and communication skills are emphasized, followed by sharing ideas respectfully and then collaborating to resolve a problem and propose possible solutions. While the organic learning experiences focus on developing social skills and building a sense of community through learning, the traditional classroom concentrates on redundant, rote activities which students complete in isolation following a textbook.

In the following section, the authors will present several authentic organic learning activities, specific classroom management strategies, and effective instructional designs used in library instruction. Librarians and teaching faculty assume the role of facilitators, using prompts, scaffolds, and models to engage learners in differentiated, dynamic research processes and inquiry-based thinking. Their solicited and unsolicited coaching motivates learners, engages them in scholarly conversations about research topics, and provides them with feedback on how to use information from sources in their research and course assignments.

\section{DISCUSSION}

\section{Pedagogical Strategies and Techniques for Successful Organic Learning: A Model}

The model described in figure 1 represents some of the pedagogical strategies and techniques which authors of this paper are using in their library instructional classes for organic learning. Each method is discussed in detail in next parts of this section. 


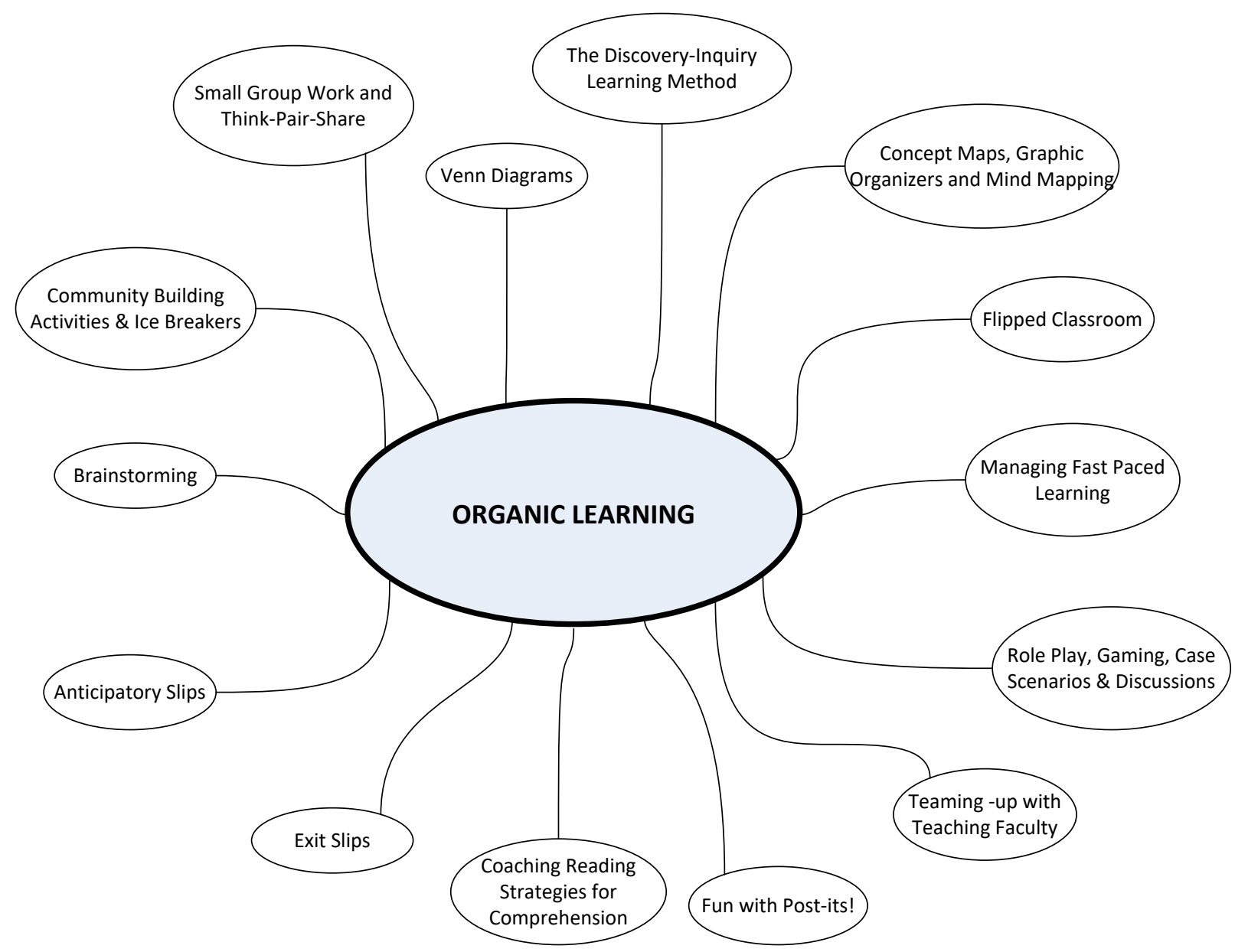

Figure 1: Pedagogical Strategies and Techniques for Successful Organic Learning: A Model

\section{Brainstorming}

Often students feel overwhelmed narrowing a topic. Librarians can help students find resources that will be helpful in targeting a more-focused topic. As students find resources that reveal related issues and subtopics known to them, they are more likely to be able to focus their research question or statement. Together with the librarian, peers, and the course teaching instructor, students can brainstorm potential research ideas related to the broader topic they already have. They can examine the different types of research they have already found, comparing them to additional materials they find as they narrow their topics. Engaging millennials in "scholarship as conversation" (ACRL IL framework no. 5, 2019, para. 7) and "research as inquiry" (ACRL IL framework no. 4, 2019, para. 7) will facilitate experiencing the research process, beginning with a broad topic and the narrowing it so that it becomes more focused. Graphic organizers or concept maps will help learners sketch out their subtopics in a visual aid, helping them discern what they already have, what they still need to find, and what they can eliminate because it is superfluous.

Librarians can help students brainstorm by walking through the course assignment, asking students what they have already done and supporting their next step in the research process. Sometimes students prepare a draft of the paper and then ask for further assistance from 
librarians so that they can enhance the information in their research with additional sources. This is an excellent way to brainstorm for precise information, making use of a variety of information sources from different mediums. In addition, it demonstrates that learners are learning how to research by thinking of related topics and other data that will support their research topics; this activity is supported by ACRL IL framework no. 3, "information has value" (2019, para. 7).

Brainstorming can be done at different stages of the research process, engaging learners in reflection, inquiry-based thinking, synthesizing concepts to experiences or findings, and expanding students' understanding of scholarly investigations by continually exploring, inquiring, discovering, and creating new knowledge by writing about it in their papers. This experience is in sync with "information creation as a process" (ACRL framework no. 2, 2019, para. 7).

\section{Flipped classroom}

With the advent of technology, library instructors can introduce undergraduates to information sources without seeing them in class or at the reference desk. Librarians and classroom instructor can apply differentiated methods that facilitate teaching students with preferences for serving particular learning styles. Rivera (2015) revealed benefits of application of flipped classroom model in library instruction as compare to traditional methods. He highlighted it as worthwhile method to overcome the challenge of insufficient time available in library instruction classes as well as to enhance teaching learning experience. Undergraduates can begin research in advance, prepare exercises ahead of time, and attend the class ready to ask questions about their research topic. It immediately allows students to engage in self-directed learning which helps them to take ownership of their own research.

The authors of this paper provide several examples of possible exercises that students can prepare on their own prior to coming to class or a consultation. These exercises can be customized to a particular course's research assignment requirements. Below are some activities that can be used in a flipped classroom:

1. Complete the online tutorials available on library website,

2. Compare search results in individual databases and to those of discovery searches

3. Compare search results in Google to those of library databases

4. Compare citation features in open web to those in library databases

5. Find keywords and subject terms in library resources; write the keywords and subject terms down as notes; briefly explain their relationship to the research topic.

6. Search streaming video databases for documentaries and related information to design questions and area of inquiry etc.

The authors have found flipped classroom method to be very useful in research consultations, library one-shots, and credit-bearing information literacy courses. The flipped classroom can also be done with teaching faculty who are amenable to co-teaching an information literacy lesson. 


\section{Concept maps, graphic organizers, and mind mapping}

Several different types of concept maps are available for free on the internet and in subscription library databases which can enhance learning experience of students. The authors of this paper noticed that in many of their instruction classes as well as in research consultation sessions that students are thrilled to learn about the feature of mind mapping and topic finder available to them in some research databases such as Credo Reference and Gale Virtual Reference Library. It helps them to narrow as well as broaden the focus of their research topics. The authors of this paper found the mind maps are not only useful for understanding and creation of content analysis but the visual features of concept mapping available in databases are helpful in sparking light bulb moments in their students which prepares them well for life-long self-regulated learning.

\section{Role playing, gaming, case scenarios and discussions}

Role playing activities such as gallery walks, playing games, and discussing case scenarios in class are very beneficial to stimulate learning experience. For example, as students engage in activities with their peers in class, organic learning occurs through enjoyable team collaborations, inquiry, discovery, and exploration.

The class room activities provide space, time and dialog with peers which facilitates communication and socialization to discuss perspectives on the given problem/area of study. As students ask questions, they gain a better understanding of the lesson or research activity from a variety of opinions. Role playing helps to cultivate social communicative competencies and strengthens team-building skills. Through ongoing scholarly discussions, students can freely ask questions to fill information gaps in their research with support from their peers.

\section{Small group work and think pair share}

Organic learning, or student-directed learning, involves collaboration, community building, and team work. Cooperation and collaboration with others is important in conducting research, especially when soliciting feedback from peers. Small group work also involves introverted learners who oftentimes have knowledge but are skeptical about contributing in large groups. Small group work and pair share activities allow these learners to participate, contribute, and help others who might not have acquired as much knowledge yet. While impulsive learners might overlook important details, introverts observe minutia, contributing unique perspectives to research projects. Collaboration builds relationships among students so that they feel comfortable and supported, and this type of learning environment will build individual learners' self-esteem and self-efficacy. Developing cooperative and collaborative skills is in sync with the ACRL framework nos. 1, 2, 4, 5, and 6 (ACRL Frameworks, 2019) which are necessary in developing lifelong learning skills. Librarians can assign different tasks to group members such as coordinator, taskmaster, spokesperson, note taker, and others. Assigning everyone a task involves all group members. Each individual is held responsible for completing a task, building on each one's strengths and weaknesses. Small group work and pair share are excellent opportunities to prepare learners for the work environment. 


\section{Anticipatory slips}

Giving students anticipatory slips at the beginning of class acts as catalyst for multi-layered lessons. It immediately sparks curiosity in undergraduates' inquisitive minds so that they wonder about the new information that will soon be presented. Before students start searching and perusing result lists, librarians can distribute anticipatory slips to elicit scholarly discussions related to research anxiety and angst. Then, learners will feel free to share their pre-conceived ideas, or fears, without being overcome by anxiety or feel embarrassed. Anticipatory guides can be used for the following reasons:

Sets the stage for the upcoming lesson, planting the seeds so that students' curiosity is sparked.

Prepares learners for predicting, anticipating ideas presented in the text, and verify their predictions.

Builds new knowledge upon prior knowledge, increasing students' interest in the topic. (WETA Public Broadcasting, 2018)

Librarians can customize anticipatory slips or guides to create an authentic learning experience based on learners' needs. Collaborating with teaching faculty on anticipatory prompts will also be helpful in targeting specific learning outcomes. Anticipatory slips can be differentiated, creating more complex prompts or questions for advanced learners while those who need more support can use simpler guides. In whole class share, anticipatory slips or guides are a convenient, quick way to transition to the upcoming lesson while engaging learners. The authors have discovered that using this technique creates an enjoyable and productive learning experience.

\section{Exit slips}

Librarians can use exist slips as a formative assessment to solicit student feedback about what they have learned and what they are still confused about. When students complete exit slips, they provide instructors with immediate feedback. Thus, librarians and instructors can use these as comprehension checks.

Students increase their metacognitive skills by reflecting on lessons, reflecting on what they have learned, and thinking critically about what they still need to find and gather for their research assignments. Writing comments on exit slips allows learners to share their ideas and thoughts with the instructors as well as acknowledge their own successful learning as responsible individuals (WETA Public Broadcasting, 2018).

\section{Venn diagrams}

Using Venn diagrams help students organize complex abstract ideas visually so that they can start to organize their ideas, evaluate what they have gathered, and pose more questions that will lead to more precise or missing information that may be missing. Librarians can use Venn diagrams as formative assessment; they provide immediate feedback about students' progress. 
With this information, millennials are more willing to contribute their ideas and ask questions in whole class share.

Venn diagrams are primarily a "thinking tool," enabling students to categorize information visually so that they can discern relationships between two or among three sets of items (ARBS, 2018, para. 2). With Venn diagrams, students can easily understand similarities, difference, and common areas.

\section{Fun with Post-its!}

Using post-its is a simple, enjoyable way to elicit feedback from learners. This tool is also a versatile way to engage learners to think about their own learning. For example, an instructor can distribute three different colored post-its to learners, asking them to answer the following questions:

\section{YELLOW: What do I already know?}

\section{GREEN: What do I want to learn?}

BLUE: What am I still confused about?

If time allows, students can be invited to share their post-its on poster paper which can be hung on the walls and/or boards with masking tape. Having learners move around the room/lab to view the post-its supports "scholarship as conversation," "research as inquiry," (ACRL Frameworks, 2019, para. 7) community building and collaboration, and organic learning.

Instructors can customize questions, prompting students to reflect on, and synthesize, their ideas related to the lesson. They will autonomously take responsibility for their own learning by becoming aware of what they have learned based on previous knowledge. Having students' complete post-its is another painless way to facilitate critical thinking about the research process, stimulating collaboration among peers.

\section{Coaching reading strategies for comprehension}

Community college and four-year college students are usually new to research. Their experience in finding authoritative sources is often limited to searching Google and they have not developed critical thinking skills to assess and evaluate information found on the web. Students frequently ask whether the websites' top level domains - including .com, .gov, .org, or .edu -- will guarantee that the information is accurate, timely, and authoritative. They do not realize that reading the text carefully to verify the facts is part of the research process. Other times, they seem relieved to find sources that are suitable for their topics, but they do not know what to do once they have the articles. Librarians can be helpful to students at this point in their research.

As students enter college having less and less exposure to different types of reading and at various levels of difficulty in reading, they need guidance with reading techniques, including skimming articles rather than relying completely on the abstract and keywords. Learners are accustomed to being spoon-fed information written in basic language. They can absorb small chunks of knowledge without necessarily recognizing how to expand their knowledge. 
Librarians can encourage students to scan the article, looking at the bold headings, gleaning the main ideas from the introduction and conclusion, and scanning data in tables and diagrams as well as finding the explanations in the text. Undergraduates can discuss how they plan on using the information with librarians during research consultations. Providing mind maps and graphic organizers helps students to organize their ideas, particularly incorporating information from sources in their papers. Librarians might recommend using the following strategies in order to understand what they are reading: summarizing, sequencing, inferencing, comparing and contrasting, drawing conclusions, self-questioning, problem-solving and synthesizing background knowledge. Afterwards, students might want to follow up with a research consultation or reference desk visit to engage in more dialogue about their research topic.

\section{Community-building activities and ice breakers}

Organic learning depends on collaborative exercises in the classroom. Using ice breakers and community building activities at the beginning of class facilitates "scholarship as conversation," team building to engage in "research as inquiry," peer discussions related on "information having value," (ACRL IL Frameworks, 2019, para. 7) and recognizing research as exploration, discovery, and enlightenment.

\section{Managing the fast pace of millennials}

Today's learners are easily distracted by portable device. They are accustomed to being entertained by games and social media. Their online world provides them with instant gratification. It is safe to say they are fast paced as they want everything and an end product quickly. Undergraduates appreciate the companionship that receive from texting and instant messaging. Therefore, millennials experience culture shock when they have to slow down and dedicate time to research.

Often times, undergraduates find it difficult to set aside time for their studies, be attentive to their course work, and self-discipline themselves in adhering to regular and consistent study routines. Engaging students in classroom activities distracts them temporarily from using their portable devices. During these short intervals of time, instructors can teach students information literacy skills in chunks with instant gratification. One way to engage learners is to keep them busy searching in a variety of sources and using different information communication technologies for searching. When library instructors change activities every eight to ten minutes during a lesson, they execute an effective classroom management technique for learners who are fast paced. As a result, they create an optimal learning environment for student-centric and selfmanaged acquisition of new knowledge and increased skills.

Similarly, at the reference desk and during research consultations, it is important to engage students, guiding them in conducting their own searches, learning how to change the word order of phrases, changing names to acronyms and vice versa, etc. Teaching information literacy requires practice, and students learn by conducting their own searches rather than relying on the librarian to find materials for them. Even though it is faster, and easier, for the librarians to find relevant sources for students, millennials need to develop self-confidence and selfefficacy by regularly searching for their own information sources. Practicing research strategies 
supports students' developing and improving search techniques so that they access the most relevant information for their topics. Afterwards, they must dedicate time to reading the materials carefully and judiciously selecting ideas to integrate in their research assignments. Each stage of research requires time, dedication, and practice.

\section{The Discovery-inquiry learning method in library instruction}

Both the education and library and information science fields use the terms discovery and inquiry with respect to learning; yet, the terms have different meanings in these distinct but related fields. Discovery library instruction affords librarians, teaching faculty, and students the opportunity to experience the best of both worlds by using elements of discovery from both disciplines-education and library science (Buck \& Steffy, 2013; Hammer 1997).

In education, Hammer (1997) argues that "[d]iscovery learning approaches, in particular, are designed to engage students in inquiry through which, guided by the teacher and materials, they "discover" the intended content" (p. 485). He contends that discovery teaching occurs when instructors manage students' unintended discoveries as well as the intended discoveries. Successful "discovery teaching" depends on librarians' and course instructors' unanticipated perceptions and insights as they explore and discover, and even learn from students (Hammer, 1997, p. 485). Ultimately, successful discovery teaching and learning with regard to information literacy will include scholarly conversations based on a series of inquiries about the intended and unintended findings of students, librarians, and teaching faculty. With regard to the meaning of discovery in library world, proprietary and open source vendors have been developing discovery tools - also called web-scale discovery tools - to "accommodate patrons and make library searching easier and more attractive" to users (Buck \& Steffy, 2013, p. 67). Because users/students learn from information sources, library science has borrowed and re-applied the term discovery from education, cognitive psychology, and related disciplines. Buff and Steffy (2013) maintain that "discovery tools streamline searching and aim to provide a user-friendly experience that meets the expectations of today's user. While these tools simplify the search experience, the results still require refinement" (p. 67). In teaching students how to use discovery tools, librarians and teaching faculty must facilitate student learning through guided activities and anticipate that they will make unintended as well as intended discoveries.

Millennials' hyperactivity and short attention spans interfere in learning complex concepts. Librarians should limit explanations and dedicate more time to classroom activities. When millennials search and gather information in databases, they will encounter issues, prompting them to wonder, ask more questions, and conduct more search strategies, and engage in scholarly conversations.

\section{Teaming-up with teaching faculty on library instruction}

Team-teaching with course teaching faculty is a strategic way to render the information literacy lessons meaningful. Teaching faculty often understand the resources that are needed in their field so students take their advice seriously. Teaching faculty know more about their students' strengths and weaknesses than a librarian (Kim, 2016; Lindstrom \& Shonrock, 2006: Isbell, 1995). Therefore, when teaching faculty are engaged in information literacy lessons, learners will, most likely, consider co-teaching class instruction important and participate actively in class 
activities. When everyone contributes to scholarly conversations and asks questions, learning is enjoyable and productive.

\section{CONCLUSION}

One size does not fit all is very true for our diverse students' learning experiences. In organic learning, students learn from experience and their engagement at different capacities and intellectual levels throughout a self-directed and self-managed learning process. Organic learning unconsciously involves students in the learning process, engaging them in several stages of research without pressuring them to practice redundant exercises and/or rote exercises. Students experience a sense of wonder, become inquisitive, and pose questions, engaging in scholarly conversations with peers and educators.

Designing instructional materials and lessons that target undergraduates' learning outcomes can be successfully realized by applying organic learning techniques in library instruction, research consultations, and reference sessions. Organic learning can be fun and seamless, alleviating research anxiety and stress among students. Students take ownership of their own learning in organic learning environment and perform research efficiently.

Organic learning demands that librarians and course teaching faculty strategically design and plan classroom instruction that is targeted towards clearly defined and explicit learning outcomes. This creates a win-win situation for all - librarians, course teaching faculty, and especially students.

Above all, organic learning sets the stage for undergraduates' success in academic, professional, and personal endeavors by developing lifelong learning skills based on supportive scholarly conversation and inquiry-based learning. The authors highlighted a model for pedagogical strategies and techniques which have been successful in their information literacy classes. These pedagogical strategies and techniques can be adapted for library instruction in any type of library.

\section{References}

Ashton-Warner, S. (1986). Teacher. New York, NY: Simon \& Schuster. (Originally published 1963).

Association of College \& Research Libraries. (2016, January 11). Framework for information literacy for higher education. In Guidelines, Standards, and Frameworks. Retrieved May 15,2018 , from http://www.ala.org/acrl/sites/ala.org.acrl/files/content/issues/infolit/Framework_ILHE.pd f

Bandura, A. (1999). Exercise of personal and collective efficacy in changing societies. In A. Bandura (Ed.), Self-efficacy in Changing Societies (pp. 1-45). Cambridge, United Kingdom: Cambridge University Press. (Originally published 1997).

Bruner, J. S. (1957). Going Beyond the Information Given. New York: Norton. 
Bruner, J. S. (1960). The Process of Education. Cambridge, Mass.: Harvard University Press. Bruner, J. S. (1961). The act of discovery. Harvard Educational Review, 31, 21-32.

Bruner, J. S. (1966). Toward a theory of instruction, Cambridge, Mass.: Belkapp Press.

Bruner, J. S. (1973). The relevance of education. New York: Norton.

Buck, S., \& Steffy, C. (2013). Promising practices in instruction of discovery tools.

Communications in Information Literacy, 7(1), 66-80. https://doi-

org.www.library.manhattan.edu/10.15760/comminfolit.2013.7.1.135

Carey, M.P., \& Forsyth, A.D. (2019). Teaching tip sheet: Self-efficacy. In American

Psychological Association: Public Interest Directorate. Retrieved June 9, 2019, from https://www.apa.org/pi/aids/resources/education/self-efficacy

Clark, M. (2017). Imposed-inquiry information-seeking self-efficacy and performance of college students: A review of the literature. Journal of Academic Librarianship, 43(5), 417-422. doi: org/10.1016/j.acalib.2017.05.001

Cohen, M. E. (2016). The flipped classroom as a tool for engaging discipline faculty in collaboration: A case study in library-business collaboration. New Review of Academic Librarianship, 22(1), 5-23. doi:10.1080/13614533.2015.1073162

Cooperstein, S. E., \& Kocevar-Weidinger, E. (2004). Beyond active learning: A constructivist approach to learning. Reference Services Review, 32(2), 141-148. doi: 10.1108/00907320410537658

Coorey, J. (2016). Active learning methods and technology: Strategies for design education. International Journal of Art \& Design Education, 35(3), 337-347. doi:10.1111/jade.12112

D'Angour, A. (2013). Leisure and play in Plato's teaching and philosophy of learning. American Journal of Play, 5(3), 293-307. Retrieved on March 29, 2018, from: https://files.eric.ed.gov/fulltext/EJ1016076.pdf

Dewey, J. (1910). How We Think. Boston: D.C. Heath.

Drew, S. (2001) Student perceptions of what helps them learn and develop in higher education. Teaching in Higher Education, 6(3), pp. 309-331. https://doi.org/10.1080/13562510120061197

Elder, G. (1999). Life trajectories in changing societies. In A. Bandura (Ed.), Self-efficacy in Changing Societies (pp. 46-68). New York, NY: Cambridge University Press. (Originally published 1997).

Elzen, A.M.V., \& Roush, J. (Spring, 2013). Brawling in the library: Gaming programs for impactful outreach and instruction at an academic library. Library Trends, 61(4), 802813. doi:10.1353/lib.2013.0016

Ferster, C. B., \& Skinner, B. F. (1957). Schedules of reinforcement. New York, NY: Prentice Hall.

Finch, J. L., \& Jefferson, R. N. (2013). Designing authentic learning tasks for online library instruction. The Journal of Academic Librarianship, 39(2), 181-188. doi.org/10.1016/j.acalib.2012.10.005 
Gordon, C. A. (2010). The culture of inquiry in school libraries. School Libraries Worldwide, 16(1), 73. Retrieved March 28, 2018, from: https://search-proquestcom.www.library.manhattan.edu/docview/217752221?pq-origsite=gscholar

Hammer, D. (1997). Discovery learning and discovery teaching. Cognition and Instruction, 15(4), 485-529. Retrieved from http://www.jstor.org.www.library.manhattan.edu/stable/3233776

Hunnicutt, B. K. (1990). Leisure and play in Plato's teaching and philosophy of learning. Leisure Sciences: An Interdisciplinary Journal, 12(2), 221-227. doi.org/10.1080/01490409009513101

Isbell, D. (1995). Teaching writing and research as inseparable: a faculty-librarian teaching team. Reference Services Review, 23(4), 51-62. https://doiorg.lib2.bmcc.cuny.edu/10.1108/eb049264

Joyce, C. (2008). Venn diagrams. In ARBs: Assessment Resource Banks. Retrieved June 10, 2019, from https://arbs.nzcer.org.nz/venn-diagrams

Kim, J. (2016, November 16). The librarian on the teaching Team: An essential partnership. In Inside Higher Ed: Technology and Learning. Retrieved June 25, 2019, from https://www.insidehighered.com/blogs/technology-and-learning/librarian-teaching-team

Lee, E., \& Hannafin, M. (2016). A design framework for enhancing engagement in studentcentered learning: Own it, learn it, and share it. Educational Technology Research \& Development, 64(4), 707-734. doi:10.1007/s11423-015-9422-5

Lindstrom, J., \& Shonrock, D.D. (2006). Faculty-librarian collaboration to achieve integration of information literacy. Reference \& User Services Quarterly, 46(1), 18-23.

Lewin, K., \& Lewin, G.W. (Ed.). (1948). Resolving Social Conflicts: Selected Papers on Group Dynamics. New York: Harper \& Row.

Morrison, D. (2014, February 14). Is learning scientific or organic? In Online Learning Insights: A Place for Learning About Online Education. Retrieved May 1, 2019, from https://onlinelearninginsights.wordpress.com/2014/02/06/is-learning

Ozga, J., \& Sukhnanden, L. (1998, July 1). Undergraduate non-completion: Developing an explanatory model. Higher Education Quarterly, 52(3), pp. 316-333. https://doi.org/10.1111/1468-2273.00100

Peterson, D. (2017, March 6). How ice breakers will make you a better teacher of adult students. In ThoughtCo. Retrieved April 3, 2019, from https://www.thoughtco.com/ice-breakersmake-you-better-teacher-31245scientific-or-organic/

Piaget, J. (1932). The Moral Judgment of the Child. London: Routledge \& Kegan Paul Piaget, J. (1936). Origins of Intelligence in the Child. London: Routledge \& Kegan Paul. Piaget, J. (1945). Play, Dreams and Imitation in Childhood. London: Heinemann.

Piaget, J. (1957). Construction of Reality in the Child. London: Routledge \& Kegan Paul. Piaget, J. (2013). The Growth of Logical Thinking from Childhood to Adolescence. London: Routledge. https://doi.org/10.4324/9781315009674. (Originally published 1958). 
Piaget, J., \& Cook, M. T. (1952). The origins of intelligence in children. New York, NY: International University Press.

Rivera, E. (2015). Using the flipped classroom model in your library instruction course. Reference Librarian, 56(1), 34-41. https://doiorg.lib2.bmcc.cuny.edu/10.1080/02763877.2015.977671

Scheerens, J. (2015). Educational Effectiveness and Ineffectiveness: A Critical Review of the Knowledge Base, p. 4. Retrieved from https://ebookcentral-proquest-com.rdasproxy.mercy.edu

Skinner, B. F. (1938). The Behavior of Organisms: An Experimental Analysis. New York: Appleton-Century.

Skinner, B. F. (1948). 'Superstition' in the pigeon. Journal of Experimental Psychology, 38(2), 168-172. http://dx.doi.org/10.1037/h0055873

Skinner, B. F. (1951). How to Teach Animals. San Francisco, CA: Freeman.

Skinner, B. F. (1953). Science and Human Behavior. Upper Saddle River, N.J.: Pearson Education.

Teaching Excellence in Adult Literacy Staff at the American Institutes for Research, U.S. Department of Department of Education. (2010). Student-centered learning [PDF]. In TEAL Center Fact Sheet No. 6: Student-Centered Learning 2. Retrieved June 25, 2019, from https://lincs.ed.gov/sites/default/files/6\%20_TEAL_Student-Centered.pdf

Thomas, G. (2013). Education: A Very Short Introduction. Oxford, U.K.: Oxford University Press.

Thompson, N. (2000). Sylvia Ashton-Warner: Reclaiming personal meaning in literacy teaching. The English Journal, 89(3), 90-96. doi:10.2307/822103

Thoutenhoofd, E.D. \& Pirrie, A. (2015). From self-regulation to learning to learn: Observations on the construction of self and learning. British Educational Research Journal, 41(1), 72-84. doi: 10.1002/berj.3128

Tompo, B., Ahmad, A., \& Muris, M. (2016). The development of discovery-inquiry learning model to reduce the science misconceptions of junior high school students. International Journal of Environmental and Science Education, 11(12), 5676-5686. Retrieved March 28, 2018, from: http://www.ijese.net/makale/732

Vygotsky, L. S. (1962). Thought and Language. Cambridge, MA: MIT Press.

Vygotsky, L. S. (1978). Mind in Society: The Development of Higher Psychological Processes. Cambridge, MA: Harvard University Press.

Vygotsky, L. S. (1987). Thinking and speech. In R.W. Rieber \& A.S. Carton (Eds.), The Collected Works of L.S. Vygotsky, Volume 1: Problems of General Psychology (pp. 39285). New York: Plenum Press. (Original work published 1934.)

WETA Public Broadcasting. (2018). Exit slips. In Launching Young Readers! Reading Rockets. Retrieved April 3, 2019, from http://www.readingrockets.org/strategies/exit_slips 
WETA Public Broadcasting. (2018). Anticipation guide. In Launching Young Readers! Reading Rockets. Retrieved April 3, 2019, from http://www.readingrockets.org/strategies/anticipation_guide

Wingate, U. (2007). A framework for transition: Supporting 'learning to learn' in higher education. Higher Education Quarterly, 61(3), 391-405. doi: 10.1111/j.14682273.2007.00361.x

Zimmerman, B. (1990). Self-regulating academic learning and achievement: The emergence of a social cognitive perspective. Educational Psychology Review, 2(2), 173-201. https://doi.org/10.1007/BF01322178

\section{About the author}

Kanu A. Nagra, Ph.D., M.L.I.S., M.L.S., is Associate Professor and E-resources Librarian at the Borough of Manhattan Community College, City University of New York (CUNY), New York, N.Y.

Bernadette M. López-Fitzsimmons, M.L.S., M.A., M.A., is Associate Librarian for Instruction, Research, and Outreach at Manhattan College, Riverdale, N.Y. 